\title{
Truth and lies about the social rehabilitation of drug addiction
}

\author{
Panagiotis Georgakas
}

From $1^{\text {st }}$ International Congress on Neurobiology and Clinical Psychopharmacology and European Psychiatric Association Conference on Treatment Guidance Thessaloniki, Greece. 19-22 November 2009

A drug addict, after his detoxification, except for his "therapy" (abstinence from any drug use, abstinence from any criminal activities), has also to deal with his difficulties to confront or accept the social rules. And that is what rehabilitation is all about. To become able to accept the social rules is a long-term attempt to succeed in the following "rehabilitation" steps: a) Changes in the "way of thinking" b) Change of "life style" c) Development of "social skills" d) Development of "job skills" e) Cooperation with peers f) Know how to organize "free time"

Published: 22 April 2010

doi:10.1186/1744-859X-9-S1-S20

Cite this article as: Georgakas: Truth and lies about the social

rehabilitation of drug addiction. Annals of General Psychiatry 2010

9(Suppl 1):S20.
Argo-Alternative Therapeutic Program for Addicted Individuals, Psychiatric Hospital of Thessaloniki, Greece
Submit your next manuscript to BioMed Central and take full advantage of:

- Convenient online submission

- Thorough peer review

- No space constraints or color figure charges

- Immediate publication on acceptance

- Inclusion in PubMed, CAS, Scopus and Google Scholar

- Research which is freely available for redistribution

Submit your manuscript at www.biomedcentral.com/submit
C Biomed Central 